\title{
Austerity, Labour Market Reform and the Growth of Precarious Employment in Greece during the Eurozone Crisis
}

\author{
Geoff Kennedy, University of Oregon, United States
}

\begin{abstract}
This article examines the relationship between structural reforms commonly referred to as austerity and the growth of precarious labour in Greece. It argues that, in contrast to the proponents of labour market flexibility, the liberalisation of labour markets, employment protection systems, social protection systems and collective bargaining institutions have not increased employment in Greece or minimised the growth of precarious employment. Rather, liberalising structural reforms have resulted in the creation of the very precarity its proponents claim is the product of rigid labour markets, and they have failed to significantly reduce existing levels of unemployment and increasing employment rates.
\end{abstract}

\section{KEYWORDS}

Flexibility; austerity; precarity; unemployment; labour markets

\section{Introduction}

The global financial crisis - and the subsequent Eurozone crisis - has had calamitous effects on the Greek labour market. Between 2008 and 2013, unemployment rose from 7.8 per cent to over 27 per cent while employment levels plummeted. Recent structural reforms imposed under the rubric of austerity and designed to increase the flexibility of the Greek labour market have their antecedents in the failed attempts at reform in the early 2000s, as successive Greek governments struggled to comply with European Union (EU) criteria that can be traced back to the establishment of a hegemonic narrative of economic liberalisation in Europe (Ioannou, 2010). The stated intention of liberal reforms is to increase the discretionary power of employers to allocate labour in the labour market, in the belief that this will increase employment rates and reduce unemployment.

This article argues that the liberalisation of labour markets, employment protection systems, social protection systems and collective bargaining institutions have not increased employment in Greece or minimised the growth of precarious employment. Rather, these liberalising structural reforms have resulted in the creation of the very precarity that liberal reformers claim is the product of rigid labour markets, and they have failed to significantly reduce existing levels of unemployment and increase employment rates. The first section that follows examines the drive towards labour market flexibility in Europe over the course of the 1990s and 2000s, charting the rise of a hegemonic discourse of labour market flexibility among key policy-oriented institutions like the European Union and the Organisation for Economic Cooperation and Development (OECD). The second section examines some of the academic critiques of labour market flexibility and precariousness, with a specific focus on Standing's (2014) conceptualisation of the precariat. The 
third and fourth sections examine the implementation of structural reforms and assess their impact on Greek labour markets, arguing that the result has been the rise of precariousness in the context of the ongoing economic crisis.

\section{Labour Market Reform in Europe}

As the post-war class compromise broke down in the 1970s, European economies experienced rising levels of unemployment. In the 1990s, as the unemployment levels of the liberal market economies of the Anglo countries dropped below those of the continent for the first time in a generation, numerous studies were published arguing that the existence of protective labour market institutions and generous social protection regimes were creating labour market "rigidities" that were the root cause of rising European unemployment (Layard, Nickell and Jackman, 1991; Siebert, 1997). In 1994, the OECD published its Jobs Study, followed by a Jobs Strategy that proposed a series of reforms to existing labour markets and labour market institutions with the intention of solving Europe's unemployment problem. The Jobs Study pointed out that in the liberal market economies of the United States (US) and the United Kingdom (UK), unemployment demonstrated "little tendency to rise over the long term" and that "unemployment rate differentials by age, gender and skill have either narrowed or remained stable over the last decade (OECD, 1994: 55). This low unemployment, however, was accompanied by "an increase in earnings inequality and large falls in real wages for low-skilled workers" (OECD, 1994: 55). The situation on the Continent was quite different. In Europe, "employment growth has been generally sluggish and there are substantial numbers of 'outsiders' who are excluded from gaining entry into jobs" (OECD, 1994: 55). At the same time, European labour markets displayed levels of wage compression among employed workers, resulting in real wage gains "for all workers irrespective of skill but at the cost of a shrinking number of job opportunities for low-skilled workers and a rise in their unemployment rates, in both absolute and relative terms" (OECD, 1994: 55). That the Nordic countries had, for the most part, been able to buck the trend of European unemployment despite retaining many of their traditional protective labour market institutions did not dissuade the OECD and neo-liberal reformers from their liberalising mission.

In this context, the OECD and the International Monetary Fund (IMF) promoted labour market reforms intended to enable greater adaptation to changing market conditions. Among the targets of reforms were non-wage labour costs such as employer social security contributions, high minimum wages, inflexible wage formation and wage-bargaining systems, and legislated or negotiated forms of employment security. These protective labour market institutions, it was argued, needed to be reformed or abolished in order to eliminate the rigidities in the labour market that were to blame for high levels of unemployment and declining rates of labour market participation. In this way, labour market flexibility became the stated goal of scores of reformers, including those associated with the OECD, the IMF and the World Bank.

The argument for greater labour market flexibility largely revolves around the critique of a number of protective labour market institutions and programmes of social protection including employment protection legislation (EPL), centralised or coordinated wage-setting and generous unemployment benefits.

Three major claims are commonly leveled at the rigidities that EPL introduces into labour markets. First, high levels of EPL increase unemployment by "blocking recruitment and labour turnover" (Myant and Brandhuber, 2016: 5). Given the high thresholds and high costs of dismissals, employers have difficulty shedding superfluous labour and are reluctant to hire new workers given the difficulty in letting them go should economic circumstances change. Second, it is argued that 
EPL diminishes productivity, because it inhibits the implementation of labour-saving technology. Again, given the legislative obstacles to downsizing the labour force, it becomes difficult to introduce labour-saving technology that will boost productivity. As a result, labour market rigidity will result in labour market segmentation: a secure core of workers protected by EPL will exist alongside a growing pool of the long-term unemployed who will find it increasingly difficult to break into the labour market. At best, this latter group - often comprised of new prospective entrants to the labour market - will find atypical or precarious work on the growing periphery of the labour market; at worst, they will fill the ranks of the long-term unemployed. Either way, the result is a growing dualism between labour market "insiders" and "outsiders".

Many liberal economists have argued that decentralised wage-setting mechanisms have a positive effect on reducing unemployment (Calmfors and Drifill, 1988; Aidt and Tzannatos, 2002; Heckman, 2003). Some of these arguments are nuanced and emphasise that the same outcomes result from coordinated wage bargaining systems as from uncoordinated sectoral bargaining systems. However, institutions like the IMF and the OECD have tended to favour bargaining decentralisation, arguing that national or sector-wide wage rates make it difficult for employers to adjust wages to changing economic conditions. ${ }^{1}$ While firm-level agreements enable employers to award productivity bonuses to workers, favourability clauses often prevent them from negotiating wage concessions that undercut nationally or sectorally established wage rates. Faced with declining profitability in times of economic downturn, employers cannot drive down the wages of their workers. As a result, firms cannot adjust their wage costs to changing market conditions, thereby resulting in declining rates of investment and either rising unemployment or stagnant or declining employment rates.

Finally, generous unemployment benefits are said to discourage unemployed workers from quickly re-entering the labour market and thus merely contribute to the growth of long-term unemployment (Meyer, 1990). ${ }^{2}$

At the European level, this flexibility agenda was integrated into the Delors White Paper (DWP) on Growth, Competitiveness, Employment (European Commission [EC], 1993). The DWP argued that "a large part of Europe's structural unemployment" is the result of labour market rigidities created by "specific institutional, legal and contractual circumstances in each country"; specifically, it singled out the "educational system, labour laws, work contracts, contractual negotiation systems and the social security system[s]" of each country (EC, 1993: 15). In particular, the DWP singled out the countries of southern Europe, stating that their "laws on the conditions under which workers on unlimited contracts may be laid off need to be made more flexible, with greater assistance being given to the unemployed and with less recourse to precarious forms of employment" (EC, 1993: 17). High thresholds of social protection were considered impediments to increasing competitiveness in the southern European periphery. Employment protection legislation was to be replaced by active labour market policies that emphasised lifelong learning as a means of developing human capital. Such training would be more tailored to the market by

\footnotetext{
${ }^{1}$ Nickell (1997) argues that coordinated wage bargaining can actually encourage wage moderation and bring down inflation. Calmfors and Drifill (1988) argue that centralised coordinated bargaining could bring down unemployment just as much as decentralised bargaining systems. In a similar vein, Aidt and Tzannatos (2002: 12) argue that highly coordinated bargaining can actually reduce unemployment, while poorly coordinated and less centralised bargaining can increase unemployment. Heckman (2003: 370), however, argues that a "high level of centralized wage bargaining thwarts the ability of workers and firms to act on local conditions and to bargain flexibly".

${ }^{2}$ Meyer (1990: 757) argues that "higher UI [unemployment insurance] benefits are found to have a strong negative effect on the probability of leaving unemployment".
} 
ensuring "greater involvement of the private sector in education and/or vocational training systems and in drawing up education and training policies in order to take account of market needs and social conditions" (EC, 1993: 118). Such measures, it was argued, would improve the fit between unemployed workers and the changing nature of the labour market by enhancing the human capital of the former in order to adapt more effectively to the latter. By the time the European Monetary Union (EMU) had been negotiated, and member states sought to meet the criteria for entry, the drive towards greater labour market flexibility - as the solution to Europe's unemployment problem - had become a policy priority among EU policy-makers.

\section{Critiquing Flexibility and Conceptualising Precarity}

The flexibility agenda embedded in the OECD Jobs Strategy and the project of European integration is not without its critics. As early as the late 1980s, Guy Standing (1986) raised some serious theoretical and empirical challenges to the claims made by supply-side prescriptions for labour market liberalisation. More recently, McBride, McNutt and Williams (2007) examined crossnational data on labour market liberalisation and found no positive correlation between labour market flexibility and the existence of competitive business environments as defined by the World Economic Forum (WEF). By analysing the OECD Compliance Rankings (of structural reforms) and the competitiveness rankings of the WEF's World Competitiveness Report, they concluded that cross-national comparison "suggests that the adoption of neo-liberal labour market policies does not improve either domestic labour market performance or international competitiveness" (McBride et al., 2007: 90-91). Howell, Baker, Glyn and Schmitt (2007) conducted a comprehensive review of the pro-liberalisation literature and found that proponents of weakening protective labour market institutions rely - at best - on casual associations between unemployment benefit replacement rates, employment protection levels and rates of unemployment. In terms of unemployment benefit systems, they convincingly demonstrate the lack of a causal association between cuts in benefit generosity and the tightening of eligibility criteria and declining rates of unemployment among a range of OECD countries. ${ }^{3}$ Regarding employment protection legislation, the authors point out that several low-unemployment European states have levels of EPL as high as high-level unemployment countries on the Continent, while exhibiting the low levels of unemployment characteristic of low-EPL countries like the UK, Ireland and the US. As such, the authors find "no statistical association between unemployment and standard OECD measures of employment protection laws, unemployment benefit replacement rates, the duration of unemployment benefits, union density or union coverage" (Howell et al., 2007: 16). ${ }^{4}$

More recently, Standing (2011) argues that the agenda of labour market flexibility has exacerbated the growth of the precarious and atypical forms of employment that its proponents claimed it would alleviate. The result of this has been a substantive transformation of the class structure, with the emergence of a new class he identifies as the precariat. While the extent to which the precariat constitutes a new social class is debatable, Standing's work presents us with a number

\footnotetext{
${ }^{3}$ They also suggest that the causal relationship between benefit generosity and unemployment may be reversed: that increases in benefit generosity is a response to rising levels of unemployment.

${ }^{4}$ Also, much of the literature examined by Howell et al. indicates that bargaining coordination has a positive impact on reducing unemployment, making the attempts to disorganise collective bargaining in Greece rather counter-productive.
} 
of characteristics by which to identify precarious work in the context of liberalisation. ${ }^{5}$ Standing has identified a number of troubling labour market outcomes as a result of the drive towards labour market flexibility. They provide us with useful criteria for assessing the development of precarious employment in the context of neo-liberal structural reforms.

Labour market insecurity refers to a lack of adequate employment opportunities, particularly as a result of the end of state-guaranteed full-employment policies. We can see this either in terms of declining levels of employment or, more frequently, the declining levels of standard employment, such as jobs on open-ended contracts and declining levels of full-time employment. A good indicator in this regard is the rising level of involuntary part-time employment in labour markets. Employment insecurity refers to the weakening of workers' rights against arbitrary individual and collective dismissals, often enshrined in employment protection legislation. We see this in the repeal of EPL and the increasing power of managerial discretion over workers, particularly in the form of the extension of probationary work periods in which workers can be dismissed without cause. Job insecurity refers to the erosion of traditional job descriptions and qualifications that clearly define the parameters of one's employment. This increases discretionary managerial power in the utilisation of existing labour supply in order to achieve functional flexibility. Work insecurity refers to the erosion of safe and stable working conditions, which has a negative impact on the work environment. We can see this in the weakening of health and safety regulations that protect workers on the job, but also in the erosion of limits on working time. The latter measure has become particularly common as labour market reforms have expanded the work-week - or have altered the calculation of working time to reduce the costs to the employer of overtime pay, thereby making it less expensive to expand the work-week. These are measures meant to get more labour out of the same workers without increasing labour costs. Skills reproduction insecurity refers to a decline in the opportunities to gain, retain and upgrade skills through vocational training programmes and apprenticeships. Officially, the EU reform agenda is committed to strengthening skills reproduction security. However, the implementation of this commitment is uneven at best. In the case of Greece, as will be discussed in detail below, there has been little investment in vocational training programmes or active labour market policies. Income insecurity refers to the decline of income protections such as minimum wages that keep up with inflation, cost of living increases or wage indexation as well as comprehensive social security - such as unemployment benefits and family allowances - that prevent the income of workers from eroding due to unemployment or stagnant wages. Representation insecurity refers to the erosion of the rights of trade unions to collectively bargain, to organise or to strike. This can take the form of reforms that minimise the monopoly that trade unions have on representation rights for workers in the workplace, or it can take the form of legislation that makes it easier to decertify unions, such as the so-called right-to-work laws common in the United States. Such reforms enable "associations of persons" to enter into collective wage agreements with employers in the absence of trade union representation, which may be more inclined to challenge the authority of management. The result of these various insecurities is an increase in the general insecurity of workers operating within the formal labour market and can be used as criteria to assess the degree of precarious employment.

In an attempt to quantify labour market insecurity, the OECD has developed a metric that combines unemployment risk with earnings loss (OECD, 2018d). Unemployment risk is calculated by correlating monthly unemployment flows with the expected duration of unemployment. Earnings loss is calculated in relation to existing social protection policies - namely, income support through unemployment benefits. In this sense, the weakening of EPL in a context of high

${ }^{5}$ For a critique of the precariat as a new class formation, see Palmer (2014). 
unemployment coupled with the significant cuts to unemployment benefits should result in increasing levels of labour market insecurity over the course of the crisis period. This is indeed the case: by the OECD metric, Greek workers have experienced a dramatic rise in labour market insecurity since the onset of austerity in 2009-2010. When categorising workers by age and educational attainment, we see some very significant trends. As Tables 1 and 2 indicate, young Greeks (ages 15-29) with secondary or post-secondary non-tertiary education are entering a labour market characterised by extraordinarily high levels of insecurity. Labour market insecurity, therefore, is not merely a form of precarity that is experienced by the unskilled. Rather, it is a condition that is increasingly experienced by young workers with medium levels of educational attainment.

Table 1: Labour market insecurity by age, 2006-2014

\begin{tabular}{|l|l|l|l|l|l|l|l|l|l|}
\hline Age & $\mathbf{2 0 0 6}$ & $\mathbf{2 0 0 7}$ & $\mathbf{2 0 0 8}$ & $\mathbf{2 0 0 9}$ & $\mathbf{2 0 1 0}$ & $\mathbf{2 0 1 1}$ & $\mathbf{2 0 1 2}$ & $\mathbf{2 0 1 3}$ & $\mathbf{2 0 1 4}$ \\
\hline $15-29$ & 19.16 & 18.58 & 16.05 & 23.35 & 41.91 & 60.68 & 84.20 & n. d. & n. d. \\
\hline $30-49$ & 6.08 & 6.24 & 5.37 & 9.06 & 17.05 & 20.16 & 25.10 & 31.52 & n. d. \\
\hline $50-64$ & 3.35 & 3.29 & 3.41 & 7.51 & 10.97 & 11.99 & 14.92 & 18.03 & n. d. \\
\hline
\end{tabular}

Source: OECD, 2018d

Note: The numbers indicate percentage of earnings loss expected from unemployment.

Table 2: Labour market insecurity by education, 2006-2014

\begin{tabular}{|l|l|l|l|l|l|l|l|l|l|}
\hline & $\mathbf{2 0 0 6}$ & $\mathbf{2 0 0 7}$ & $\mathbf{2 0 0 8}$ & $\mathbf{2 0 0 9}$ & $\mathbf{2 0 1 0}$ & $\mathbf{2 0 1 1}$ & $\mathbf{2 0 1 2}$ & $\mathbf{2 0 1 3}$ & $\mathbf{2 0 1 4}$ \\
\hline HIGH & n. d. & 6.89 & 5.59 & 8.28 & 15.60 & 17.57 & 20.26 & 28.10 & n. d. \\
\hline MED & n. d. & 8.91 & 7.35 & 13.11 & 22.82 & 26.07 & 33.69 & 42.85 & n. d. \\
\hline LOW & n. d. & 7.03 & 6.94 & 10.74 & 18.76 & 26.11 & 33.92 & 40.52 & n. d. \\
\hline
\end{tabular}

Source: OECD, $2018 d$

Note: The numbers indicate percentage of earnings loss expected from unemployment.

As a result, a growing percentage - over a quarter - of Greeks have transitioned into jobs characterised by weaker employment security than that of their previous employment (Figure 1). At the same time, a declining proportion of Greeks - 73.1 per cent in 2014, down from 88.3 per cent in 2009 - transitioned into jobs with the same or higher employment security. By far the worst affected are the recently unemployed: 85.8 per cent of Greeks transitioning from unemployment to employment take up jobs with less employment security than their lost job.

According to the OECD's own data, then, increasing employment insecurity is a characteristic of the current Greek labour market under conditions of austerity. While no data exists after 2013, the trajectory is clearly one of increasing insecurity. Given the implementation of reforms designed to increase the flexibility of labour markets and to cut back public spending on social protection, it is reasonable to conclude that the levels of OECD-defined labour market insecurity are continuing to rise.

However, the OECD's definition of labour market insecurity only provides a partial measure of insecurity and precarity, as it does not take into account other important aspects, such as the absence of what Standing (2011) calls representation security, skills reproduction security, work security and income security. ${ }^{6}$ For our purposes, we can take three of these into account: skills

\footnotetext{
${ }^{6}$ Employment security may be implicit in the OECD's measure of inflows of unemployment. Insofar as weakening EPL results in an immediate shedding of workers, we can assume that this insecurity is covered in the indicator.
} 
reproduction security, income security and representation insecurity. In terms of skills reproduction security, we will see how the implementation of active labour market policies (AMLPs) in Greece has been insufficient: Greece has prioritised employment subsidies over long-term vocational and educational training programmes (VETs), thereby limiting the opportunities available to workers employed and unemployed - to upgrade their skills in order to adapt to changes in the labour market.

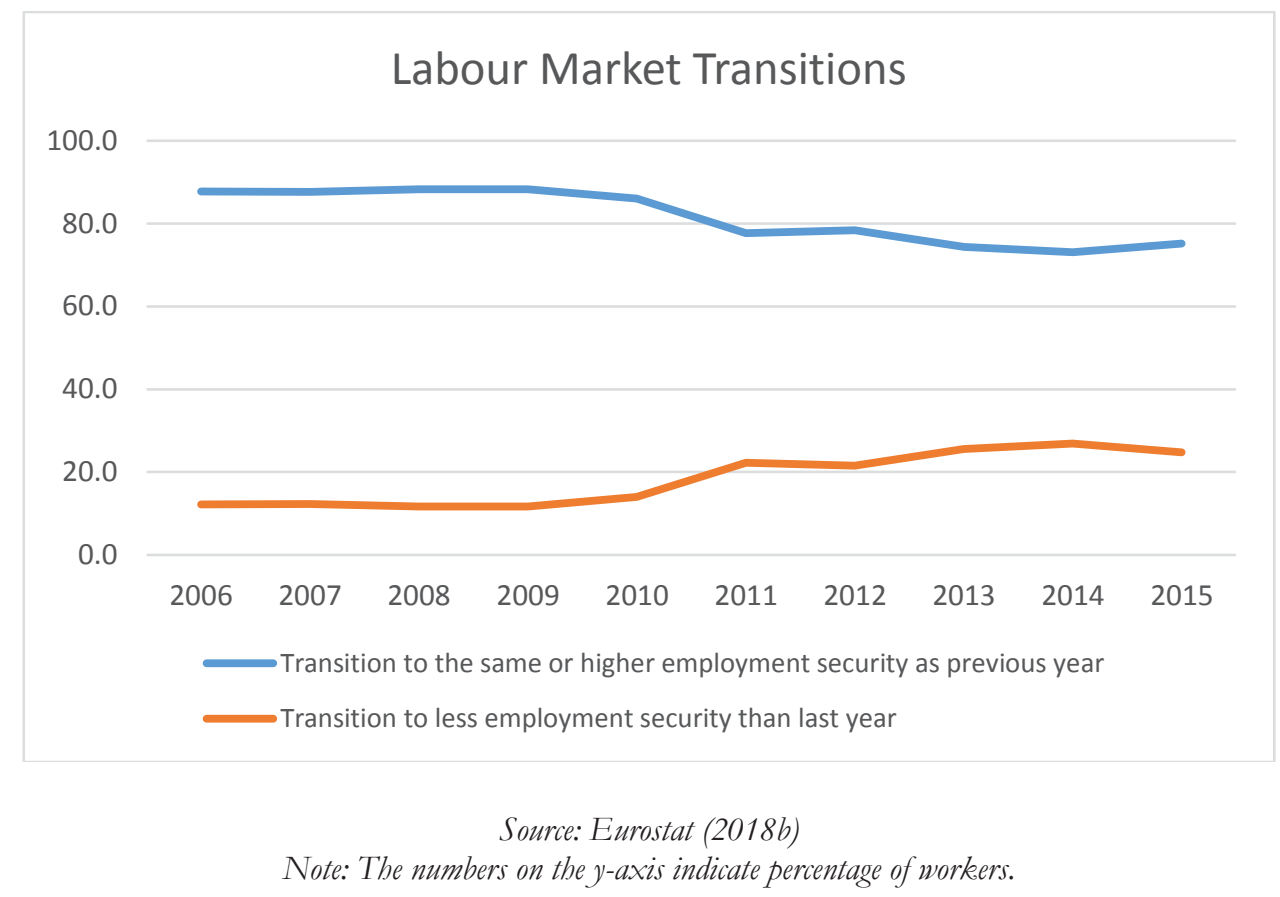

Figure 1. Labour market transitions

Income security, as we will see, has been significantly weakened both by the dramatic reductions in the minimum wage and by the proliferation of firm-level collective agreements that have imposed wage concessions on workers in light of the abolition of the favourability principle in Greece's multi-level collective bargaining system (Kennedy, 2016). In this sense, labour market insecurity should not merely be understood in terms of expected earnings loss in light of unemployment, but also the loss of employment-based income as a result of increasing liberalisation and the subsequent change in the nature of employment relations.

Finally, representation insecurity is a product of the weakening of collective bargaining and trade union representation. In particular, there has been a proliferation of non-union "associations of persons" granted the legitimate right to sign collective agreements with management. This weakens the autonomous representation of workers, as the ability of these associations of persons to effectively withstand employer pressure in the absence of union support declines. As Boukalas and Müller (2015: 395) argue, these associations of persons are "completely unregulated" and "their independence from the employer is neither stipulated nor safeguarded". In the context of the decline of collective bargaining coverage, a result of the abolition of automatic administrative extension mechanisms, and the decline of sectoral bargaining, an increasing segment of the 
workforce is exposed to the arbitrary power of employers. In this sense, the OECD understates the degree of labour market insecurity in Greece if we conceptualise this insecurity as the kind of precariousness articulated by Standing.

\section{Austerity, Structural Reforms and the Greek Crisis}

In 2012, the European Commission released its report, Labour Market Developments in Europe. The report provided an intellectual rationalisation for the radical reform of existing labour markets and wage-setting mechanisms in the countries hardest hit by the financial crisis. Its authors argued that employment protection legislation was "linked to reduced dynamism of the labour market", resulted in the growth of precarious employment, and hampered the "process of macroeconomic rebalancing" (EC, 2012: 4). The reform of EPL systems, therefore, "appears as a key driver for reviving job creation in sclerotic labour markets while tackling segmentation and adjustment at the same time" (EC, 2012: 4). The report suggests that reforms "promoting wage adjustment are also key to absorb effectively unemployment while favouring the price competitiveness gains that are needed for the correction of current account deficits" (EC, 2012: 4). In this sense, the report can be taken as the official view of the EU regarding the reform process that has been underway since the early days of the financial crisis (Hermann, 2014, 2017). Such reforms were required of countries like Greece as a condition for receiving so-called bailout funds from the Troika - the EU, the European Central Bank (ECB) and the IMF. Labour markets were to be made more flexible and employment would be incentivised. The reforms fall into a number of categories: reforms to wage bargaining and collective bargaining systems; reforms to social protection systems; and reforms to labour markets and employment protection legislation (Kennedy, 2016). Each of these are discussed below.

\section{Employment protection legislation}

The weakening of employment protection has been a prevalent response to the crisis and a significant component of austerity. Greek $\operatorname{Law}^{7}$ 3863/2010, passed in July 2010, lowers the threshold on collective dismissals, making it easier for employers to lay off workers. Previous legislation allowed employers to dismiss up to four workers per month in firms employing between 20 and 200 workers, and up to 2 per cent of the workforce for larger firms. The new law raises the threshold to six for firms employing between 20 and 150 employees, and to 5 per cent of the workforce for firms employing more than 150 workers. The reforms to employment protection legislation also shorten the duration of the layoff notification period for long-term white-collar workers from twenty-four months to six months, and reduce the level of severance pay. Other reforms, such as Law 3899/2010, passed in December 2010, contains provisions increasing the power of management over workers by extending probationary periods from two to twelve months, lengthening the period in which workers can be arbitrarily dismissed without compensation.

The Greek government also consented to the implementation of reforms designed to increase flexibility in the labour market by enabling the use of part-time and temporary employment. ${ }^{8} \mathrm{On}$

\footnotetext{
7 Unless otherwise specified, "Law" refers to "Greek Law" in this article.

8 The most significant legislative changes regarding temporary employment were introduced in 2003.
} 
11 May 2010, the PASOK 9 government passed Law 3846/2010, legalising new flexible labour arrangements such as part-time work and the use of temporary employment agencies. The law also increases the length of temporary contract work from eighteen to thirty-six months, thereby reducing the incentives for employers to hire workers on a permanent basis, a move the OECD (2011: 18) characterised as "positive". Secondly, the prohibition against using temporary work agencies (TWAs) for public-sector employment (and therefore, hiring temporary workers in the public sector) was suspended for three years. In the following year, Law 3919/2011 rolled back some of the administrative barriers to setting up TWAs, thereby increasing the supply of temporary workers in the labour market.

As a result of these changes, Greece's ranking in the OECD index of employment protection legislation for individual and collective dismissals has declined from 2.80 (out of 6) in 2010 to 2.11 in 2013, placing it just ahead of Ireland on the index (see Figure 2). EPL rankings for temporary employment contracts have declined less - from 2.75 in 2010 to 2.25 in 2012 - but only because they had been significantly liberalised in 2003 .

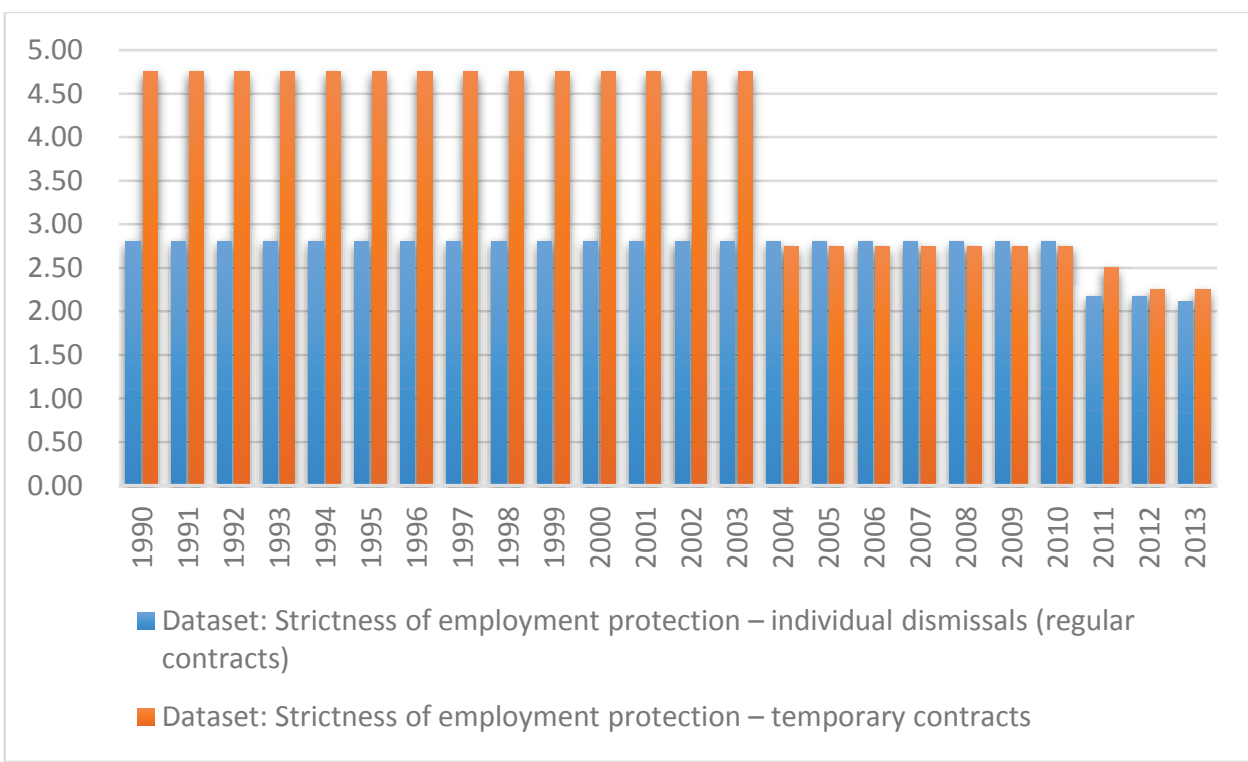

Source: OECD (2018i).

Figure 2: Employment protection in Greece, 1990-2013

\section{Collective bargaining coverage}

Structural reforms targeting the transformation of collective bargaining institutions have resulted in a dramatic decline in collective bargaining coverage among Greek workers. Like many continental European countries, levels of collective bargaining coverage in Greece are not determined by levels of trade union density. Administrative extension mechanisms extending collective agreements to workplaces that are non-unionised but that are mandatory members of

\footnotetext{
${ }^{9}$ PASOK is the Panhellenic Socialist Movement, founded in 1974 by Andreas Papandreou as a democratic socialist and left-wing nationalist party.
} 
the main employers' associations result in very high rates of collective bargaining coverage. However, since the onset of the financial crisis, Greece has experienced the greatest decline in collective bargaining coverage of any OECD country. Data from the International Labour Organization (ILO) indicates that collective bargaining coverage in Greece has declined to just over 40 per cent of the workforce in 2013, down from 85 per cent in 2008 prior to the implementation of structural reforms (ILOSTAT, 2018). Declining coverage is not primarily a result of declining levels of union density, but is rather a result of the abolition of the automatic administrative extension mechanisms.

The duration in which the terms of a collective agreement remain in force upon the expiration of the agreement has also been reduced. Under previous legislation, the terms of an expired agreement remained in force for six months; even after the six-month period, the conditions of work stipulated in the collective agreement continued to apply "until the termination or amendment of individual employment contracts" (Papadimitriou, 2013: 16). Law 4046/2012 reduces the extension period to three months, and the continuation of the conditions of work after the expiration of the three-month period does not include all work conditions, but only a portion of the salary. On 2 July 2015, the Syriza ${ }^{10}$ government passed Law 4331/2015, which repealed the amendments of Law 4046/2012, effectively restoring the provisions of the previous collective bargaining legislation. However, the Euro Summit statement of 12 July 2015 - after the capitulation of Syriza, following their victory in the July 5 austerity referendum - demanded a return to the austerity legislation of Law 4046/2012 by 15 September 2015.

National-level bargaining that determines the minimum wage has also been effected by the structural reforms implemented in the context of the crisis. In November 2012, the coalition government of New Democracy-PASOK-Democratic Left (DIMAR) passed Law 4093/2012, which granted government the power to determine the minimum wage. Prior to this, the minimum wage was the result of collective bargaining between the social partners at the national level. At the beginning of 2013, the government reduced the monthly minimum wage by 22 per cent, and by 32 per cent for those younger than 25 years of age, effectively introducing a sub-minimum wage with the highest age threshold in Europe.

Finally, a new law makes it easier for employers in firms with less than fifty workers, where no unions are present, to enter into collective agreements with associations of persons, thereby allowing them to bypass unions altogether and to undermine the principle of democratic, collective representation. Legislation from the 1980s (Law 1264/1982) enabled employers to conclude agreements with associations of persons, but only under certain conditions: they could be concluded only in the absence of a labour union, pertain to the resolution of a specific issue, and exist for a limited period of time. Law 4024/2011 significantly weakens the criteria that must be met in order to conclude these non-union-based collective agreements. Most important, the law eliminated previous limits to the lifespan of such associations of persons, turning them into "nebulous non-elected" entities that facilitate the ability of employers to drive down wages and benefits in an attempt to increase competitiveness through a reduction in labour costs - which is, of course, the intention of the structural reform process (Lanara, 2012: 8). Indeed, evidence suggests that small business has taken advantage of this new law in order to negotiate companylevel agreements with "less favourable provisions than those of the relevant sector agreement" (Eurofound, 2014: 11). One commentator has characterised Law 4024/2011 as "one more step toward the demolition of two of the most powerful pieces of legislation to be enacted in Greece since 1974: laws 1264/82 and 1876/90" (Kopsini, 2011).

\footnotetext{
${ }^{10}$ The Coalition of the Radical Left (Syriza) was founded in 2004 as a coalition of left-wing and radical-left parties.
} 


\section{Social protection and unemployment benefits}

The stated intention of reforms to the social protection system is to increase its efficacy through the greater targeting of benefits. As Matsaganis (2005: 24) points out, Greece has a “'perforated' social safety net that fails to prevent the descent of a sizeable proportion of the population into extreme poverty". At same time, Greece has been traditionally characterised by very low levels of unemployment benefits. In 2009, at the outset of the crisis and before austerity reforms, the net replacement rates of Greek unemployment benefits averaged 30 per cent of employment income for single earners, 28 per cent below the EU median (OECD, 2018j). Yet, even this low net replacement rate masks the perforated nature of the Greek system: not only does this refer to unemployment insurance that is linked to specific types of employment and is determined by rather strict eligibility requirements, the Greek system is characterised by the absence of a universal income scheme in the form of unemployment assistance - the universal unemployment benefit that kicks in after the depletion of the employment-based unemployment insurance benefit. In terms of net-replacement rates for the long-term unemployed, Greece has consistently occupied the bottom of the league. ${ }^{11}$

Throughout the crisis, Greek governments have struggled to balance the Troika's demands for fiscal consolidation with the need to prevent the acceleration of poverty in the context of rising unemployment. In terms of unemployment benefits, successive governments have increased the net benefit replacement rates for unemployed workers with children. In some instances, net replacement rates were increased by 15-20 per cent between 2012 and 2013 (OECD, 2018j). The net replacement rates for workers with no children have also increased slightly since the onset of the crisis. At the same time, however, spending on social protection and unemployment benefits have been significantly reduced from 2011 onward (Figures 3 and 4). ${ }^{12}$

This can be partially explained by the impact of declining average wages on net replacement rates for unemployment benefits. Between 2007 and 2015, average wages declined by at least 20 per cent, with the steepest decline occurring between 2009 and 2013. Most increases in the net replacement rates have been offset by this decline in average wages which serves as the "peg" against which unemployment benefits are calculated. In this sense, even the most substantive increases in the net replacement rate only hold the line on the monthly monetary value of the benefits received. Between 2008 and 2009, at the early stages of the crisis, the New Democracy government increased the net replacement rate of unemployment benefits and increased the coverage (from $€ 349.5$ a month in 2007 to $€ 454$ a month in 2009 - gross benefit) in response to a significant rise in unemployment in the last quarter of 2008. However, submitting to the Troika's financial assistance programme in 2010 resulted in a substantial reversal of this expansion of unemployment benefits. In 2012, the caretaker government of Lucas Papademos slashed unemployment benefits by a further 22 per cent in compliance with the Troika's programme. Given that the benefit rate was pegged to the minimum wage, the reduction of the latter resulted in a

\footnotetext{
${ }^{11}$ For workers with no children.

12 While EU rhetoric emphasises the need to compensate for increased labour market flexibility with more effective social protection, reforms targeting the former have clearly been prioritised at the expense of the latter, particularly in the context of austerity. As a result of the Troika's insistence on fiscal consolidation, spending on social protection has decreased significantly since the onset of the crisis. As Figure 2 shows, levels of social protection spending are now at pre-2006 levels, when Greece was enjoying above EUaverage levels of growth and a decline in unemployment. Not only is the current level of spending approximately half the EU and Euro-area average, its downward trajectory diverges from the rising levels of social protection spending in the EU and Euro-area.
} 
corresponding reduction of the former. As a result, aggregate spending on out-of-work income maintenance supports dropped to 0.598 per cent of GDP in 2013 from 0.714 per ent at the outset of the crisis in 2010, declining every year despite rising levels of unemployment (see Figure 4). In 2014 it dropped further to 0.47 per cent despite persistently high levels of unemployment, and despite the fact that, from 2013 onward, self-employed Greeks were able to access unemployment benefits for the first time.

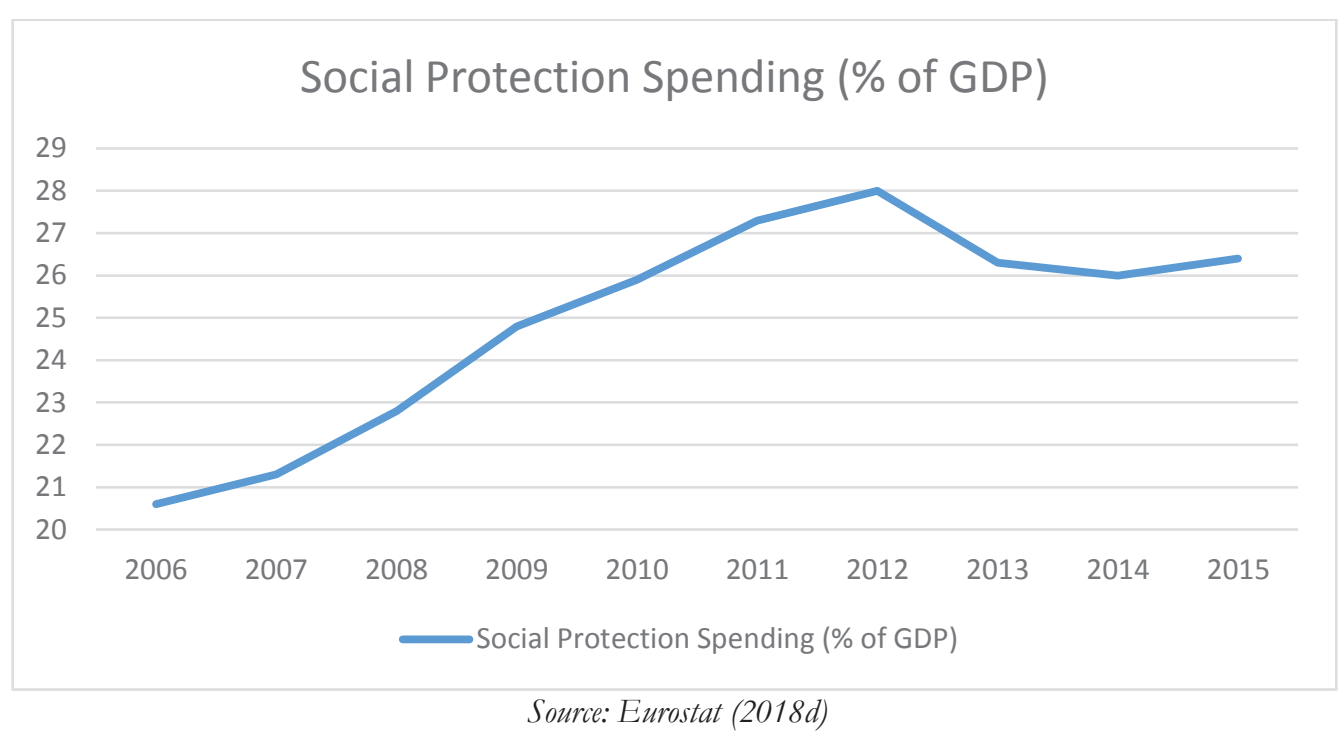

Figure 3. Social protection spending in Greece, 2006-2015

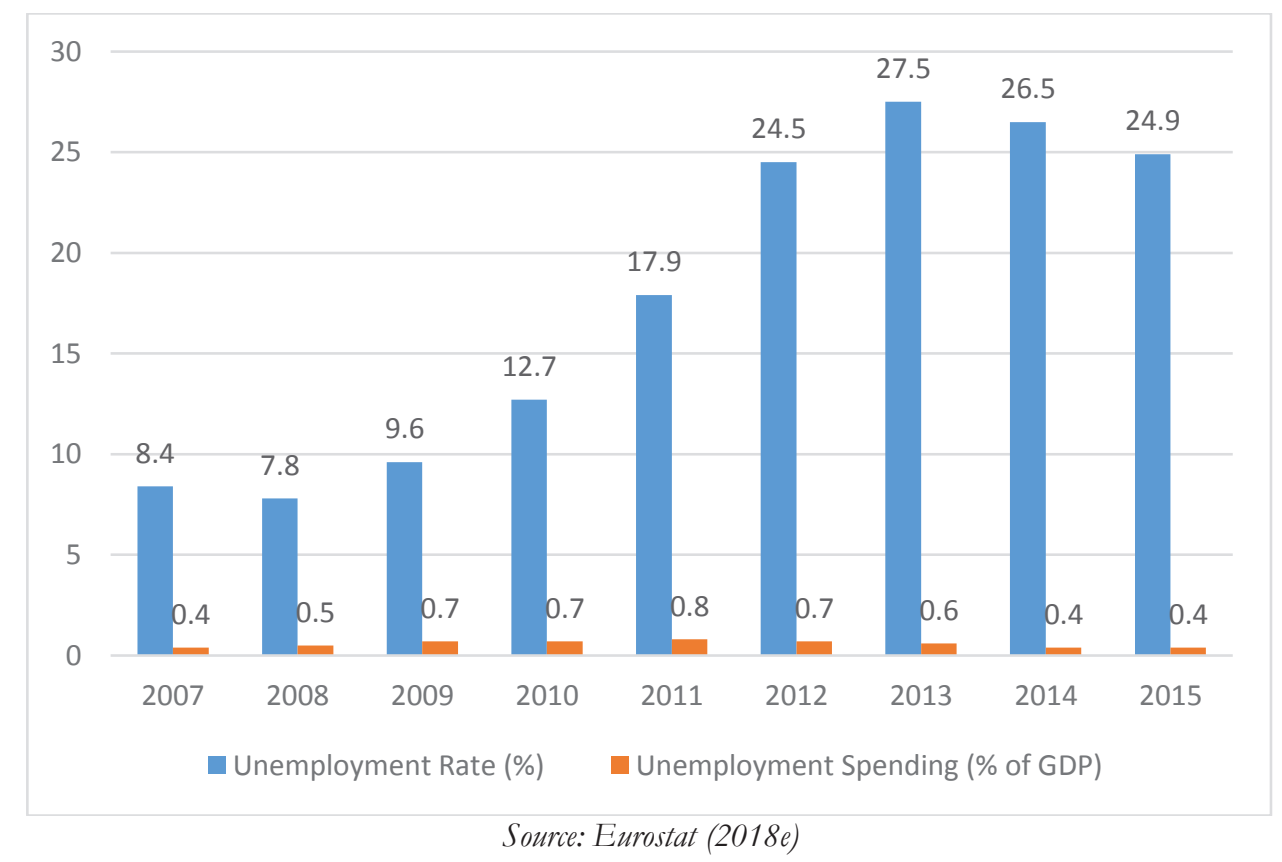

Figure 4. Unemployment and unemployment spending, 2007-2015 
Despite the increases in unemployment assistance coverage for the long-term unemployed, the relief amounts to $€ 200$ per month and is available only to those applicants with an annual household income of less than $€ 10000$. In comparison, however, long-term unemployment assistance in Greece continues to remain low, and in the context of the economic crisis it remains insufficient. The net replacement rate for long-term unemployment sits at 9 per cent while the fiveyear replacement rate is 17 per cent, placing Greece ahead of only Italy and Turkey on both counts. ${ }^{13}$ As it stands, Greece has one of the lowest levels of unemployment benefits in Europe.

Despite the recent increases to net replacement rates, unemployment benefit generosity and coverage has been reduced due to the dramatic decline in wages, to the growth of part-time and temporary employment, and to the persistence of high unemployment and long-term unemployment. ${ }^{14}$ As a result, by 2014, Greece still had the second-lowest net replacement rate (for single earners with no children) in the EU, at 39 per cent (OECD, 2018j). While this replacement rate remains slightly higher than the rate in the pre-crisis period, it remains significantly below the EU median of 68 per cent and even further below the 75 per cent average rate in Italy, Portugal and Spain (OECD, 2018j). In monetary terms, the 2012 reforms amounted to a reduction of the monthly benefit from €461 to €360 per month, a move that even the OECD (2013: 39) characterised as a regressive reform that negatively affected low-income households.

While the stated intention of the reforms was to introduce targeted benefits that cut costs while maintaining coverage, the targeting process amounts to the introduction of means tests for the unemployed (Hellenic Republic Ministry of Finance, 2011: 81). Law 4093/2012 (passed in December) reduced the seasonal and special unemployment benefits for the unemployed within specific geographical regions and those within certain professions. As such, the coverage of contributory unemployment insurance benefits declined between 2010 and 2013 despite its extension to the self-employed. In 2010, 65 per cent of the short-term unemployed were receiving benefits; by 2012, that had dropped to 50 per cent. As the reforms were being introduced, the Labour Institute of the General Confederation of Greek Workers warned that the reforms would result in only 165000 out of one million jobless Greeks receiving benefits in the summer of 2013. By 2016, Elstat reported that 90 per cent of jobless workers in Greece received no unemployment benefit (Kathimerini, 2016).

\section{Active labour market policies}

The architects of structural reforms often emphasise the importance of compensating for the reduction in unemployment benefits by introducing active labour market policies (ALMPs) that are intended to facilitate the re-entry of the unemployed into employment. In particular, training and re-skilling have been touted as a way of increasing employment rates and alleviating precarity. Pontusson (2005: 130) has argued that while evidence to support the claim that ALMPs increase employment rates is rather thin, "shifting support for the unemployed from passive to active measures tends to reduce the duration of unemployment and possibly also the rate of unemployment".

However, data shows that Greece has been a laggard in regard to the development and implementation of ALMPs. Between 1999 and 2015, Portugal, an economy with a similar economic profile to that of Greece (including a relatively equivalent GDP during the 1990s), devoted on

\footnotetext{
${ }^{13}$ Averages based on one-earner couples with two children, earning average wages.

14 OECD (2018k) data indicates a 20 per cent decline in average wages between 2007 and 2015, with the steepest decline occurring between 2009 and 2013. Low-wage jobs grew by 6 per cent between 2012 and 2014 (OECD, 2018k).
} 
average $€ 434$ million per year on training alone, amounting to roughly three and a half times Greece's annual average of $€ 121$ million over the same period (Eurostat, 2018c). Between 2009 and 2010, at the outset of the crisis, spending on labour market training in Greece declined 88 per cent despite the significant rise in unemployment. In 2010, labour market training accounted for only 0.017 per cent of GDP - a mere 7.6 per cent of the EU-15 average (Eurostat, 2018c; OECD, 2018f). By 2014, this had risen to 0.126 per cent of GDP but has since declined to 0.088 per cent as a result of fiscal constraints. Again, the contrast with Portugal is instructive: between 2008 and 2009, when unemployment began to rise considerably, the Portuguese government increased spending on skills and training for unemployed workers from 0.23 per cent to 0.41 per cent of GDP (OECD, 2018f). In terms of labour market expenditure, Greek governments spent more money on employment incentives to businesses, in contrast to Portugal where the total spent on employment incentives amounted to less than half of what was spent on training. Out of forty ALMPs implemented between 2008 and 2014 in Greece, only seven were classified as training programmes, consisting of training in tourism and green jobs, basic IT and communications training, on-the-job training in SMEs, and training vouchers in mining, shipping and journalism. An additional four programmes were special schemes for youths. In contrast to this, twelve policies were employment subsidies to private business, encouraging them to hire the unemployed.

In light of the Greek case, it is important to emphasise the limits of ALMPs, particularly in the context of an economic crisis. As Pontusson argues:

During employment crises, when there are very few jobs to be had, active labor market measures tend to lose their distinctive quality and to evolve into passive income support for the unemployed under a different label. In short, active labor policy does not by itself constitute an 'employment strategy', and, beyond a certain point, the payoffs of government spending on active labor market policy are likely to diminish (Pontusson, 2005: 128).

As a result, even if Greek governments committed to more ALMPs, the current state of dramatically high unemployment and declining investment would nullify their effects.

It may, of course, be the case that Greece is suffering from poor policy implementation - that the prioritisation of reducing labour market rigidities and employment protection has contributed to the failure of the few ALMPs that have been introduced. Galata and Chrysakis (2016: 24) conclude that the introduction of ALMPs in Greece during the crisis suffers from a "lack of longterm, coherent and well-coordinated design of policy interventions", and that this problem is partly the result of the lack of resources due to the needs of fiscal consolidation. In this case, we are led back to Pontusson's (2005) insight that AMLPs may not be effective when being implemented in the context of an unemployment crisis, such as the case of Greece. But it also leads to some challenging conclusions regarding the politics of structural reform in Greece: that given the underdeveloped nature of the Greek welfare state (as indicated in the low level of unemployment benefits and unemployment assistance) it is understandable why Greek workers are resistant to attempts to liberalise employment protection legislation prior to the introduction of effective AMLPs.

However, it may also be the case that the supply-side logic of the ALMP agenda is incapable of dealing with the structural specificities of the Greek economy - specificities that have become increasingly pronounced structural weaknesses as a result of the Eurozone crisis. For example, ALMPs rest on the assumption that the problems of unemployment and/or low employment levels are the result of the lack of skilled labour (as opposed to the lack of demand by employers for skilled labour). Labour market rigidities make it difficult to fire existing staff and introduce younger, 
more skilled workers to replace them. Similarly, the absence of worker training programmes serves to inhibit firms from increasing investment and expanding their operations within the country. ALMPs presume that, given an increase in this supply of skilled labour, firms will efficiently utilise that skilled labour in productive ways, largely through expanding firm operations. This tends to neglect the ways in which firms may rely on strategies of exploiting low-wage labour (particularly in a country like Greece). It also neglects the significance of craft-based or artisanal manufacturing in an economy that may not be amenable to the type of re-skilling promoted by ALMPs which have been successful in countries like Denmark. To put it quite simply, Greece's economic profile is that of a peripheral economy that bears many of the legacies of dependent development that may not be sufficiently appreciated by the architects of ALMPs.

\section{Precarious Labour Market Outcomes}

Reforms to wage-setting, unemployment benefits and employment protection have had significant impacts on the evolution of the Greek labour market. In contrast to the claims of the supporters of reforms, however, the outcomes have been anything but positive on growth and employment rates.

\section{Patterns of employment and unemployment}

In contrast to the stated outcomes of labour market liberalisation as presented by its proponents, the Greek economy has not experienced any significant reversal of fortune of its labour market woes as a result of the structural reforms implemented under the rubric of austerity. Between 2000 and 2008, employment levels in Greece were steadily rising as the economy experienced levels of expansion above the EU average. When the fnancial crisis hit, employment levels began to drop from 2009 onward. After the 2012 labour market reforms, employment levels continued to drop, bottoming out at 48.5 per cent in the third quarter of 2013; from there, they rose back to their prereform levels, topping out at 52.3 per cent in the third quarter of 2016 (OECD, 2018b). While the employment rate rose to 54 per cent by the third quarter of 2017 , this remains well below the EU and Euro Area averages and is significantly lower than the pre-crisis high of 61.5 per cent reached in 2008 (OECD, 2018b). Furthermore, in all age categories, we see disturbing employment trends. Youth employment (15-24 years) rose slightly in 2014, reaching a high of 13.91 per cent in the third quarter (OECD, 2018b). While it dropped down to 13.46 per cent by the end of 2016, this is still less than half of what it was back at the start of the millennium, and 41 per cent of the EU19 average (OECD, 2018b). In fact, Greece's youth employment rate exceeds only that of South Africa in the OECD league tables. Similarly, the employment rate of 55-64 year olds is second to last, exceeding only that of Turkey, at 33.6 per cent, which is two-thirds that of the EU19 average (OECD, 2018b). Finally, 2016 employment rates for 25-54 year olds exceed only those of Turkey and South Africa, at 66 per cent, or 85 per cent of the EU19 average (OECD, 2018c). At the same time, the size of the labour force has shrunk from 2009 onwards - contracting by 5 per cent between 2009 and 2016, in contrast to the 1.3 per cent expansion of the labour force in the EU19 (OECD, 2018e). The percentage of 15-34 year olds that comprise the labour force and the population has declined since the onset of the crisis. This means that the decline in youth unemployment that started in 2013 may have been a result of young people either dropping out of the labour market by either choosing to live longer with parents or to stay in school; or it may have 
been the result of increased youth migration to other parts of Europe - or both. ${ }^{15}$

Labour market reforms have also not had a positive effect on long-term unemployment. While Greece has typically had a higher rate of long-term unemployment than most European countries, by 2016, 72 per cent of all the unemployed had been jobless for one year or longer - second only to the Former Yugoslav Republic of Macedonia (OECD, 2018g). This represents a significant increase from the pre-crisis low of 40.3 per cent in 2009. In fact, it is the only category of unemployment by duration that has not declined in the context of the crisis. Thus, three years after the introduction of significant labour market reforms intending to promote job creation, the Greek labour market has been demonstrating significantly unimpressive employment growth, and persistently high levels of long-term unemployment.

\section{Part-time employment}

The new millennium witnessed a steady rise in part-time employment from a low point of 4.7 per cent in 2001 to 7.7 per cent in 2007, just at the onset of the crisis (OECD, 2016). By 2015, the parttime employment rate had reached 11.1 per cent (OECD, 2016). While this is relatively low compared to countries like the UK and is significantly below the EU average, it represents a high level for contemporary Greece. While proponents of labour market reforms often encourage the growth of part-time employment, its growth is also a point of concern, particularly if part-time employment replaces, rather than supplements, the growth of full-time employment. In the Greek case, part-time employment growth has outpaced full-time employment growth, suggesting that it is replacing full-time employment. More importantly, the growth of part-time employment during the crisis period has been dominated by the growth of involuntary part-time employment. Since the 1990s, involuntary part-time employment as a percentage of total part-time employment had been on the increase in Greece. After a decline between 2004 and 2008, the percentage of involuntary part-time employment rose again, dramatically, from 41.6 per cent of part-time employment in 2008 to 68.8 per cent in 2015 (see Figure 5). A higher incidence of involuntary part-time employment points to problems of underemployment that may be characteristic of growing precariousness. The disproportionate growth of involuntary part-time employment represents either a structural deficiency of full-time employment in the labour market (particularly for those with higher levels of education or skills), or a preponderance of poorly educated, low-skilled underemployed workers.

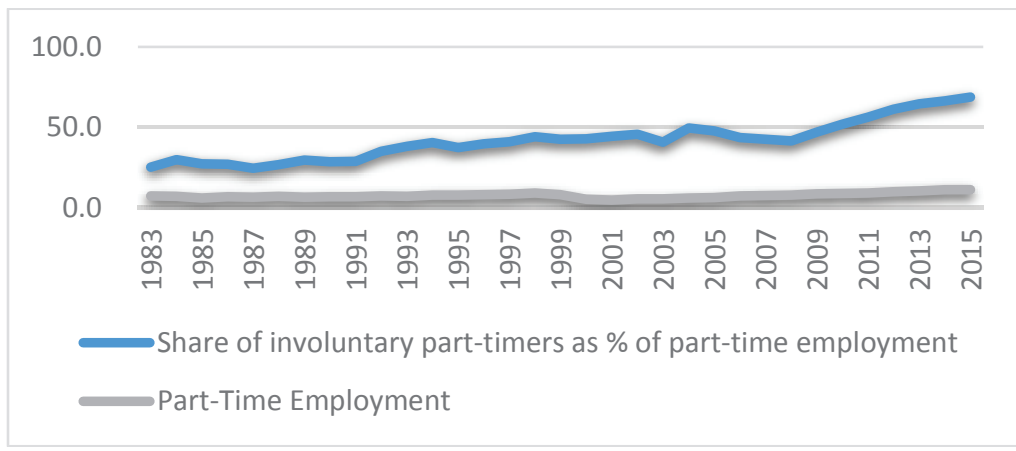

Source: OECD, 2016.

\section{Figure 5: Part-time employment}

\footnotetext{
15 According to a report published by Greece's Central Bank, 427000 young Greeks left Greece between 2008 and 2016 (Deutsche Welle, 2016).
} 


\section{Temporary employment}

Temporary employment was an immediate casualty of the crisis. In the initial months, temporary employment levels dropped from 12.6 per cent of employment in 2010 to 10.1 per cent at the beginning of 2013 (OECD, 2017). In the aftermath of the changes to labour market policy in 2010 and 2012, the temporary employment rate rose to 11.95 per cent by 2015 (OECD, 2017). This is partly the result of the above-mentioned changes to labour market policy, which has made it more attractive for employers to hire workers on a temporary basis.

If we break down temporary employment by age, we see that, not surprisingly, young workers comprise the largest portion of temporary workers (Table 3). However, the incidence of temporary employment has increased in every age category, with young people and workers in the 64 and over age category accounting for the bulk of the increase (6.9 and 12.4 percentage points respectively) (OECD, 2017). It seems that austerity - in particular, the changes to labour market policy and to collective bargaining - is reversing the general decline of temporary employment that occurred in Greece from the late 1990s onwards. Greece is seeing a return to 1980s levels of temporary employment.

\section{Table3: Temporary employment by age group (\% of workforce)}

\begin{tabular}{|l|l|l|l|}
\hline Age Group & $\mathbf{2 0 1 3}$ & $\mathbf{2 0 1 4}$ & $\mathbf{2 0 1 5}$ \\
\hline $\mathbf{1 5}-\mathbf{2 4}$ & 26.4 & 29.4 & 33.3 \\
\hline $\mathbf{2 5}-\mathbf{5 4}$ & 9.62 & 11.05 & 11.05 \\
\hline $\mathbf{5 5 - 6 4}$ & 7.38 & 7.82 & 9.26 \\
\hline 65 and over & 5.4 & 16.7 & 17.8 \\
\hline
\end{tabular}

Source: $O E C D(2017)$

\section{Self-employment}

Self-employment is a broad category that encompasses a variety of different types of employment relationships. The OECD includes employers, workers who work for themselves, workers employed by co-operatives, and unpaid family members in its category of the self-employed. As such, the self-employed relate to the labour market in profoundly different ways and may inhabit different class positions within the economy. The experience of self-employment therefore varies significantly, ranging from relative security and independence to precariousness and insecurity. As the OECD (2018h: n.p.) definition points out, self-employment "may be seen either as a survival strategy for those who cannot find any other means of earning an income or as evidence of entrepreneurial spirit and a desire to be one's own boss". Thus, to the extent that self-employment is a survival strategy rather than evidence of entrepreneurial spirit, it may contribute to the proliferation of precarious employment.

Greece has the highest rate of self-employment in Europe: 35.2 per cent of the working population were classified as self-employed in 2015 (OECD, 2018h). However, this represents a dramatic decline from the 1980s, when the self-employed comprised over half of the working population. This high level of self-employment was a feature of Greece's history of dependent development in the post-war period. In particular, it was reflective of the agrarian nature of the post-war economy - in which the land was worked by a multitude of small farmers - and the small scale, craft-based nature of Greece's urban economic development. Since Greece's entry into the European Union, levels of self-employment have declined as the labour market began to move closer to EU norms. The onset of the Eurozone crisis resulted in an immediate reversal of this 
trend as the rate of self-employment increased from 34.7 per ccent in 2008 to 36.9 per cent in 2013. It has subsequently dropped to 35.2 per cent in 2015 (OECD, 2018h).

Examining self-employment by type of economic activity may tell us a bit more about the relationship between precariousness and self-employment, as some forms of occupation have witnessed a drop in self-employment levels while others have witnessed an increase. As Table 4 demonstrates, managerial self-employment declined significantly from 2010 onward, as more and more small firms comprised of self-employed managers went bankrupt. At the other end of the spectrum, Greece has seen an equally precipitous rise in self-employed sales and service workers over the same period, suggesting a possible downward process of social mobility by the selfemployed managerial stratum. At the very least, it is reasonable to conclude that the decline of selfemployed managers and the consequent rise of self-employed sales and service workers constitutes a qualitative shift in the type of self-employment in Greece. In other words, there is a possibility that those self-employed managers have now become self-employed sales and service workers after having lost their property during the economic crisis. More evidence is needed, however, to ascertain whether this is indeed the case. If it is, such a development signifies a move away from self-employment representing the "entrepreneurial spirit" to that of a mere "survival strategy", and constitutes shift towards a greater degree of precariousness and insecurity in the labour market.

\section{Table 4: Self-employment in Greece (thousands)}

\begin{tabular}{|c|c|c|c|c|c|c|c|c|c|c|}
\hline Occupations & 2007 & 2008 & 2009 & 2010 & 2011 & 2012 & 2013 & 2014 & 2015 & 2016 \\
\hline Managers & 379.6 & 400.9 & 385.1 & 359.6 & 117 & 108.2 & 129.1 & 95.5 & 83.4 & 74.8 \\
\hline Professionals & 155.8 & 163.2 & 157.9 & 161 & 187.2 & 176.9 & 175.0 & 178.7 & 178.9 & $\begin{array}{l}180 . \\
6\end{array}$ \\
\hline $\begin{array}{l}\text { Technicians and } \\
\text { Associate } \\
\text { Professionals }\end{array}$ & 54.9 & 55.8 & 56.5 & 53.7 & 43.8 & 47.3 & 42.0 & 42.7 & 44.7 & 46.8 \\
\hline $\begin{array}{l}\text { Clerical Support } \\
\text { Workers }\end{array}$ & 9.2 & 9.5 & 8.7 & 8.2 & 14 & 15.9 & 11.4 & 12.2 & 13.3 & 13.6 \\
\hline $\begin{array}{l}\text { Service and Sales } \\
\text { Workers }\end{array}$ & 55.7 & 58.9 & 59.8 & 57.7 & 256.9 & 231 & 198.5 & 212.3 & 228 & $\begin{array}{l}236 . \\
8\end{array}$ \\
\hline $\begin{array}{l}\text { Skilled agricultural, } \\
\text { forestry \& fishery } \\
\text { workers }\end{array}$ & 321.8 & 329.2 & 347 & 359 & 333.8 & 329.5 & 337.8 & 331.7 & 318.3 & $\begin{array}{l}318 . \\
8\end{array}$ \\
\hline $\begin{array}{l}\text { Craft and trades } \\
\text { workers }\end{array}$ & 201.3 & 182.2 & 174.8 & 168.9 & 161.5 & 143.8 & 129.8 & 127.4 & 126.2 & $\begin{array}{l}122 . \\
0\end{array}$ \\
\hline $\begin{array}{l}\text { Plant and Machine } \\
\text { Operators \& } \\
\text { Assemblers }\end{array}$ & 75 & 69.7 & 75.6 & 70.5 & 67.2 & 64.2 & 59.6 & 58.7 & 57.9 & 57.9 \\
\hline $\begin{array}{l}\text { Elementary } \\
\text { Occupations }\end{array}$ & 15.6 & 16.7 & 19.3 & 21.1 & 14 & 13.6 & 11.7 & 10.6 & 9.7 & 9.4 \\
\hline
\end{tabular}

Source: Eurostat. $2018 d$

\section{Wages and working poverty}

Another aspect of precariousness as defined by Standing (2011) is the decline in income security. The percentage of jobs classified as low-wage jobs - defined by the OECD as jobs with earnings that are two-thirds or less than median earnings - has increased significantly since the implementation of the labour market reforms in 2012. While the percentage of low-wage jobs has 
been typically high in Greece, they began to decline significantly between 2006 and 2008, from 20 per cent to 13.5 per cent respectively. Low-wage jobs bottomed out at 11.8 per cent in 2012, but have since climbed back up to 17.9 per cent in 2014, as a result of the decline in minimum wages, the introduction of a sub-minimum wage for under 25s, and the general downward pressure on wages due to the transformation of collective bargaining (OECD 2018k).

The rise of low-wage employment has resulted in a subsequent increase in what Eurostat classifies as "in-work poverty". While in-work poverty slightly declined for full-time workers between 2003 and 2015, it has increased for part-time workers. Between 2009 and 2010, in-work poverty for part-timers increased by 2.5 percentage points before the first austerity legislation (Eurostat, 2018a). Between 2010 and 2011, in-work poverty for part-timers actually dropped 8 percentage points, perhaps as a result of the tripartite Economic and Social Council's (OKE) decision to increase overtime payments for part-time workers by 10 per cent. However, between 2011 and 2012, in-work poverty increased by 6 percentage points and has now reached a high of 30.3 per cent for part-time workers in 2016 (Eurostat, 2018a).

\section{Conclusion}

The growth of precarious employment in the context of structural reforms intended to increase employment and combat precarity highlights the tensions and contradictions of EU policy proposals and objectives. On the one hand, reforms to labour markets and wage-setting mechanisms are promoted with the intention of reducing unit labour costs through processes of internal devaluation - namely, the reduction of worker compensation, both in terms of wages and non-wage benefits. On the other hand, active labour market policies are promoted with the intention of increasing the opportunities available to workers to upgrade existing skills and develop news skills that can help them adapt to a changing labour market. The former objective - that of internal devaluation - is perfectly compatible with the growth of precarious employment. Here, competitiveness is enhanced, not as a result of increases in productivity, but rather as a result of reducing wages and benefits. The latter objective is oriented to the enhancement of workers' skills in order to increase competitiveness through advances in productivity. In this ideal scenario, advances in productivity are compatible with increases in worker remuneration. This scenario, however, is undermined by the predominance of the structural reforms that increase the flexibility of labour markets. The Greek case resembles the worst example of the former scenario: structural reforms have not only failed to significantly bring down unemployment and secure job growth; they have also increased the prevalence of the precarious employment that the reforms were intended - or so their proponents claim - to reduce.

\section{REFERENCES}

Aidt, Toke and Zafiris Tzannatos (2002) Unions and Collective Bargaining: Economic Effects in a Global Environment. Washington: World Bank.

Boukalas, Christos and Julian Müller (2015) Undoing Labour in Greece: Memoranda, Workfare and Eurozone 'Competitiveness'. Global Labour Journal, 6(3): 390-405.

Calmfors, Lars and John Drifill (1988) Bargaining Structure, Corporatism and Macroeconomic Performance. Economic Policy, 3(6): 13-61. 
Deutsche Welle (2016) Greece Central Bank Reports 'Brain Drain' of 427,000 Young, Educated Greeks since 2008. Deutsche Welle, 2 July 2016. http://www.dw.com/en/greece-central-bank-reports-braindrain-of-427000-young-educated-greeks-since-2008/a-19373527 (accessed 1 August 2017).

Eurofound 2014 Changes to Wage Setting Mechanisms in the Context of the Crisis and the EU's New Economic Governance Regime. Dublin: Eurofound.

European Commission (EC) (1993) Growth, Competitiveness, Employment. Brussels: EC.

European Commission (EC) (2012) Labour Market Developments in Europe. Brussels: EC.

Eurostat (2018a) In-work At-risk-of-poverty Rate. http://ec.europa.eu/eurostat/tgm/table.do?tab= table\&init $=1 \&$ language $=$ en\&pcode $=$ tesov110\&plugin $=1$ (Aacessed 11 February 2018).

Eurostat (2018b) Labour Transitions by Type of Contract - Changes in Employment Security. http://appsso.eurostat.ec.europa.eu/nui/show.do?dataset=ilc lvhl33\&lang=en (accessed: 9 February 2018).

Eurostat (2018c) Public Expenditure on Labour Market Policies by Type of Action. $\underline{\text { http:/ / ec.europa.eu/eurostat/tgm/refreshTableAction.do?tab=table\&plugin }=1 \& p c o d e=t p s 00076 \& l a}$ nguage $=$ en (accessed 11 February 2018).

Eurostat (2018d) Social Protection Expenditure: Percentage of GDP http://appsso.eurostat.ec.europa .eu/nui/show.do (accessed 9 February 2018).

Eurostat (2018e) Total Unemployment Rate and Tables by Benefits - Unemployment Function. http://ec.europa.eu/eurostat/tgm/table.do?tab=table\&init=1\&language $=$ en\&pcode $=$ tps $00203 \& p l u g i$ $\mathrm{n}=1$ \& http://appsso.eurostat.ec.europa.eu/nui/submitViewTableAction.do (accessed 9 February 2018).

Galata, Viviane and Manolis Chrysakis (2016) Active Labour Market Policies in Greece: Challenges and Responses during the Economic Crisis. Social Policy, 6: 45-66. doi: http://dx.doi.org/10.12681/sp.10880.

Heckman, James (2003) Flexibility and Job Creation: Lessons from Germany. In Knowledge, Information, and Expectations in Modern Macroeconomics: In Honor of Edmund S. Phelps, edited by Philippe Aghion, Roman Frydman, Joseph Stiglitz and Michael Woodford. Princeton: Princeton University Press.

Hellenic Republic Ministry of Finance (2011) Hellenic National Reform Programme, 2011-2014. https://ec.europa.eu/info/sites/info/files/file import/nrp greece en 0.pdf (accessed 26 February 2017).

Hermann, Christoph (2014) Structural Adjustment and Neoliberal Convergence in Labour Markets and Welfare: The Impact of the Crisis and Austerity Measures on European Economic and Social Models. Competition \& Change, 18(2): 111-130.

Hermann, Christoph (2017) Crisis, Structural Reform and the Dismantling of the European Social Model(s). Economic and Industrial Democracy, 38(1): 51-68.

Howell, David R., Dean Baker, Andrew Glyn and John Schmitt (2007) Are Protective Labor Market Institutions at the Root of Unemployment? A Critical Review of the Evidence. Capitalism and Society, 2(1): 1-71.

ILOSTAT (2018) Collective Bargaining Coverage Rate (\%). http://www.ilo.org/ilostat/faces/oracle/webcenter/ portalapp/pagehierarchy/Page27.jspx?indicator=ILR CBCT NOC RT\&subject=IR\&datasetCode= A\&collectionCode $=I R \&$ adf.ctrl-state $=$ ptn $5 \mathrm{cdxuo} 45 \&$ afrLoop $=210446213797454 \&$ afrWindow Mode $=0 \&$ afrWindowId $=$ ptn5cdxuo 42\#! (accessed 11 February 2018).

Ioannou, Christos (2010) “Odysseus or Sisyphus” Revisited: Failed Attempts to Conclude Social Liberal Pacts in Greece. In After the Euro and Enlargement: Social Pacts in the EU, edited by Philippe Pochet, Maarten Keune and David Natali. Brussels: European Trade Union Institute.

Kathimerini (2016) Nine in 10 Jobless Greeks Receive No Unemployment Benefit. 19 December 2016. http://www.ekathimerini.com/214695/article/ekathimerini/business/nine-in-10-jobless-greeksreceive-no-unemployment-benefit (accessed 2 October 2017). 
Kennedy, Geoff (2016) Embedding Neoliberalism in Greece: The Transformation of Collective Bargaining and Labour Market Policy in Greece during the Eurozone Crisis. Studies in Political Economy, 97(3): 253269.

Kopsini, Christina (2011) Collective Labor Agreements on the Way Out. Ekathemirini, 16 October 2011. http://www.ekathimerini.com/136589/article/ekathimerini/business/collective-laboragreements-onthe-way-out (accessed 5 October 2017).

Lanara, Zoe (2012) Trade Unions in Greece and the Crisis: A Key Actor under Pressure. Bonn: Friedrich Erbert Stiftung.

Layard, Richard, Stephen Nickell and Richard Jackman (1991) Unemployment: Macroeconomic Performance and the Labour Market. Oxford: Oxford University Press.

Matsaganis, Manos (2005) Greece - Fighting with Hands Tied behind the Back. In Welfare State Reform in Southern Europe: Fighting Poverty and Social Exclusion in Greece, Italy, Spain and Portugal, edited by Maurizio Ferrera.. Abingdon, UK: Routledge.

McBride, Stephen, Kathleen McNutt and Russell Williams (2007) Tracking Neo-Liberalism: Labour Market Policies in the OECD area, in Neoliberalism, State Power and Global Governance, edited by Simon Lee and Stephen McBride. Dordrecht: Springer.

Meyer, Bruce D. (1990) Unemployment Insurance and Unemployment Spells. Econometria, 58(4): 757-782.

Myant, Martin and Laura Brandhuber (2016) Uses and Abuses of the OECD's Employment Protection Legislation Index in Research and EU Policy Making. Brussels: European Trade Union Institute.

Nickell, Stephen (1997) Unemployment and Labor Market Rigidities: Europe vs. North America. Journal of Economic Perspectives, 11(3): 55-74.

Organisation for Economic Cooperation and Development (OECD) (1994) Jobs Study: Evidence and Explanations, Part I. Labour Market Trends and Underlying Forces for Change. Parisd: OECD.

Organisation for Economic Cooperation and Development (OECD) (2011) Greece: Economic Survey. Paris:OECD.

Organisation for Economic Cooperation and Development (OECD) (2013) Greece: Economic Survey. Paris: OECD.

Organisation for Economic Cooperation and Development (OECD) (2016) Incidence of FTPT Employment; Incidence of Involuntary Part-Time Workers. http://dx.doi.org/10.1787/lfs-data-en (accessed 6 June 2016).

Organisation for Economic Cooperation and Development (OECD) (2017) Temporary Employment. doi: 10.1787/75589b8a-en (accessed 24 January 2017).

Organisation for Economic Cooperation and Development (OECD) (2018a) Average Wages (Indicator). doi: 10.1787/cc3e1387-en (accessed 12 February 2018).

Organisation for Economic Cooperation and Development (OECD) (2018b) Emploment Rate (Indicator). doi: 10.1787/1de68a9b-en (accessed 9 February 2018).

Organisation for Economic Cooperation and Development (OECD (2018c) Employment Rate by Age Group (Indicator). doi: 10.1787/084f32c7-en (accessed 9 February 2018).

Organisation for Economic Cooperation and Development (OECD) (2018d) Job Quality. http://dx.doi.org/10.1787/e357cdbf-en (accessed 11 February 2018).

Organisation for Economic Cooperation and Development (OECD) (2018e) Labour Force (Indicator). doi: 10.1787/ef2e7159-en (accessed 9 February 2018).

Organisation for Economic Cooperation and Development (OECD) (2018f) Labour Market Programmes: Expenditure and Participants. http://dx.doi.org/10.1787/data-00312-en (accessed 11 February 2018).

Organisation for Economic Cooperation and Development (OECD) (2018g) Long-term Unemployment Rate (Indicator). doi: 10.1787/76471ad5-en (accessed 9 February 2018). 
Organisation for Economic Cooperation and Development (OECD) (2018h) Self-employment Rate (Indicator). doi: 10.1787/fb58715e-en (accessed 8 February 2018).

Organisation for Economic Cooperation and Development (OECD) (2018i) Strictness of Employment Protection (Indicator). http://dx.doi.org/10.1787/data-00658-en and http://dx.doi.org/10.1787/data-00319-en (accessed 9 February 2018).

Organisation for Economic Cooperation and Development (OECD) (2018j) Taxes and Benefits. http://dx.doi.org/10.1787/data-00201-en (accessed 12 February 2018).

Organisation for Economic Cooperation and Development (OECD) (2018k) Wage Levels (Indicator). doi: 10.1787/0a1c27bc-en (accessed 11 February 2018).

Palmer, Bryan (2014) Reconsiderations of Class: Precariousness as Proletarianization. Socialist Register, 50: $40-62$.

Papadimitriou, Costas (2013) The Greek Labour Law Face to the Crisis: A Dangerous Passage towards a New Juridical Nature. European Labour Law Network, Working Paper 3. Frankfurt: ELLN.

Pontusson, Jonas (2005) Prosperity and Inequality: Social Europe versus Liberal America. Ithaca, NY: Cornell University Press.

Siebert, Horst (1997) Labor Market Rigidities: At the Root of Unemployment in Europe. The Journal of Economic Perspectives, 11(3): 37-54.

Standing, Guy (1986) Labour Flexibility: Cause or Cure for Unemployment? Geneva: International Institute for Labour Studies.

Standing, Guy (2014) The Precariat: The New Dangerous Class. London: Verso.

\section{ACKNOWLEDGEMENTS}

This article arises from research undertaken as part of an ESRC-funded project entitled "Working Beyond the Border: European Union Trade Agreements and Labour Standards" (award number: ES/M009343/1). Previous versions of this paper were presented at the workshop on Global Production Networks and Social Upgrading: Labour and Beyond, University of Manchester, May 2016, and at the $10^{\text {th }}$ European Urban and Regional Studies conference, Chania, September 2016. We are very grateful to participants at these meetings for their comments and to the reviewers and editors of Global Labour Journal.

\section{BIOGRAPHICAL NOTE}

Geoff Kennedy holds a Ph.D in Political Science from York University, Canada, and has taught at universities in Canada, the United States, Ireland, the United Kingdom and Cyprus. He is the author of Diggers, Levellers and Agrarian Capitalism (Lexington, 2008) as well as numerous articles on the history of political thought and comparative political economy. He is currently working as a policy analyst for Employment and Social Development Canada. [Email: gkennedy@,uoregon.edu] 